Daytime net ecosystem exchange of carbon dioxide

\title{
Improved determination of daytime net ecosystem exchange of carbon dioxide at croplands
}

P. Zhao ${ }^{1}$ and J. Lüers ${ }^{1,2}$

${ }^{1}$ Department of Micrometeorology, University of Bayreuth, Germany

${ }^{2}$ Member of Bayreuth Center of Ecology and Environmental Research (BayCEER), University of Bayreuth, Germany

Received: 23 January 2012 - Accepted: 28 February 2012 - Published: 14 March 2012

Correspondence to: P. Zhao (peng.zhao@uni-bayreuth.de),

J. Lüers (johannes.lueers@uni-bayreuth.de)

Published by Copernicus Publications on behalf of the European Geosciences Union.

P. Zhao and J. Lüers

Title Page

Abstract

Introduction

Conclusions

References

Tables

Figures

14

4

Back

Close

Printer-friendly Version

Interactive Discussion 


\section{Abstract}

The eddy-covariance technique is applied worldwide to acquire information about carbon exchange between a variety of ecosystems and atmosphere, but the data acquisition only covers, on average, two-thirds of the whole year due to system failures 5 and data rejection. Therefore, data must be corrected and data gaps must be filled to provide seasonal or annual budgets. The gap-filing strategies, however, are still under discussion within the research community. Presently the major gap-filling methods work quite well for long-time running sites over slow-developing biosphere surfaces such as long-living evergreen forests, but difficulties appear for short-living and fastgrowing croplands. In this study we developed a new Multi-Step Error Filter procedure to gain good-quality data as input for different parameterizations of the light response function of plants for two cropland sites (rice and potatoes), and we could prove that the conventional temperature binning approach is inadequate. The presented timewindow scheme showed best results with a four-day time window for the potato field 15 and an eight-day time window for the rice field. The influence of vapor pressure deficit was tested as well, but in our case it plays a minor role at both the potato and the rice fields with the exception of the early growing stage of the potatoes. Completing our research, we suggest an innovative method by introducing a Leaf Area Index factor to capture the seasonal vegetation development. With this method we are now able to fill the large gaps between observation periods when conventional methods are invalid.

\section{Introduction}

Agricultural areas comprise nearly $40 \%$ of the land surface of the earth (Foley et al., 2005). The carbon estimate for croplands is more uncertain than for other land-use types (Janssens et al., 2003; Ciais et al., 2010). Compared to forests, the assessment surements (Gilmanov et al., 2010). The Eddy-covariance technique is well-known for

BGD

9, 2883-2919, 2012

\section{Daytime net ecosystem exchange of carbon dioxide}

P. Zhao and J. Lüers



Printer-friendly Version

Interactive Discussion 
the ability to continuously and directly quantify net ecosystem exchange (NEE) of carbon dioxide $\left(\mathrm{CO}_{2}\right)$ between the earth surface and atmosphere (Baldocchi et al., 2001; Baldocchi, 2003). Data gaps in the eddy-covariance technique, however, are unavoidable and limit the carbon budget estimate. An average of $35 \%$ of flux observations 5 are reported as missing or rejected (Falge et al., 2001). Data gaps are due to system breakdown, calibration, and maintenance, or caused by farming or human activities, or by weather conditions when the assumptions required by the eddy-covariance technique are not fulfilled (Foken and Wichura, 1996). The incompleteness of datasets requires gap-filling and correcting strategies based on the understanding of ecosystem10 atmosphere exchange (Papale, 2012).

The strategies used to obtain reliable values of NEE have drawn a lot of attention in the last decade. Many statistical and empirical approaches have been developed and discussed considering the major driving factors for NEE, i.e. the growing stages of the vegetation of interest, the light response of the plant, air or soil temperature, vapor pressure deficit (VPD), and soil water availability (Greco and Baldocchi, 1996; Falge et al., 2001). Amongst all of these, mean diurnal variation, look-up table, and non-linear regression are the most commonly used methods (Falge et al., 2001; Reichstein et al., 2005; Papale et al., 2006; Ruppert et al., 2006; Lasslop et al., 2010; Wu et al., 2012). New gap-filling methods have been developed during this period, including dual unscented Kalman filter (Gove and Hollinger, 2006), artificial neural networks (Papale and Valentini, 2003), multiple imputation method (Hui et al., 2004), and other biosphere energy-transfer hydrology models (Moffat et al., 2007). On one hand, no standard strategy is available yet in the research community owing to the imperfection of each strategy. On the other hand, these studies are focused mainly on forests, with only a few of them mentioning croplands (Falge et al., 2001; Reichstein et al., 2005). Compared to forest ecosystems, a cropland ecosystem has its own special features and requires different considerations to explain NEE and to deal with data gaps. (1) Croplands are normally patchy with a mixture of crop species, which results in mixed NEE information captured by the eddy-covariance technique. Footprint heterogeneity

\section{BGD}

9, 2883-2919, 2012

\section{Daytime net ecosystem exchange of carbon dioxide}

P. Zhao and J. Lüers

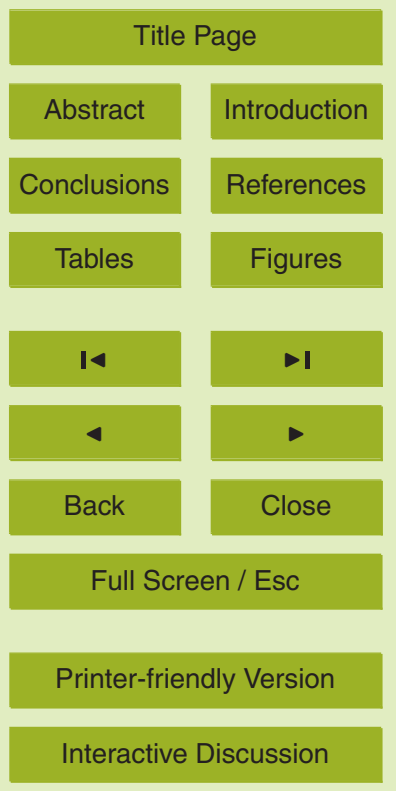


should be included to improve the performance of parameterization routines (Falge et al., 2001). (2) Many crops have growing seasons as short as two or three months, resulting in a database insufficient for some gap-filling strategies such as look-up tables and artificial neural networks. (3) The cropland canopy changes rapidly during the short 5 growing seasons, which has a strong seasonal response. Gaps during these periods could introduce more uncertainty than other periods (Richardson and Hollinger, 2007). Short time windows are needed to capture the rapid change in the $\mathrm{CO}_{2}$ exchange characteristics within a few days (Ammann et al., 2007), which enlarge the problem of data insufficiency for some strategies such as mean diurnal variation, look-up tables, 10 and non-linear regression. (4) Croplands are intensively managed and manipulated by farmers' decisions (e.g. irrigation, different planting and harvesting dates) across both regions and time (Li et al., 2011). This makes it difficult to find a universal strategy encompassing the site-specific year-to-year variation, and we found that the use of the same routine as that employed for forest sites forced unexpected errors. (5) Seasonal 15 weather patterns increase the complexity of gap-filling. For instance, the monsoon is a major factor strongly controlling the carbon budget e.g. in Asia (Kwon et al., 2010). Intensive rain, snow or storm events disturb the eddy-covariance measurements resulting in large periods without reliable observations. Furthermore, filling large gaps provides more challenge than small gaps because the change of the canopy and the underlying surface properties with time must be considered (Falge et al., 2001; Moffat et al., 2007; Richardson and Hollinger, 2007). Further investigations on croplands have been requested, and other factors such as biophysical factors are required to validate and improve the gap-filling methods (Falge et al., 2001; Moffat et al., 2007; Xing et al., 2007).

25 The objective of this study is to fulfill these requests. Firstly, we will apply several steps to create a high quality database which is required as the input to the gap-filling routine. Then we will present a new parameterization approach, including information about the growing stages of fast-developing croplands in a simple and comparable way.

\section{BGD}

9, 2883-2919, 2012

\section{Daytime net ecosystem exchange of carbon dioxide}

P. Zhao and J. Lüers

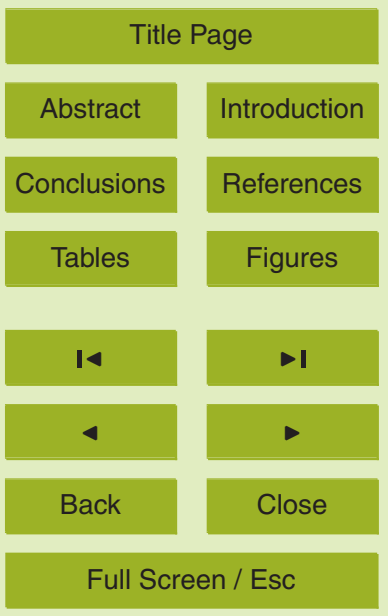

Printer-friendly Version

Interactive Discussion 
The sensitivity of the conventional methods to different parameterization approaches will also be discussed.

\section{Materials and methods}

\subsection{Data collection}

5 We carried out the observation in the field campaign 2010 of the TERRECO (Complex TERRain and ECOlogical Heterogeneity) project at Haean Punchbow, Yanggugun, Kangwon-do, South Korea, in 2010. Haean Punchbow is an intensively-used agricultural area surrounded by mountains and influenced by the Asian monsoon. We chose a potato field site $\left(38^{\circ} 16^{\prime} 38^{\prime \prime} \mathrm{N}, 128^{\circ} 07^{\prime} 28^{\prime \prime} \mathrm{E}, 455 \mathrm{~m}\right.$ a.s.l. $)$ and a rice field site $10 \quad\left(38^{\circ} 17^{\prime} 28^{\prime \prime} \mathrm{N}, 128^{\circ} 07^{\prime} 52^{\prime \prime} \mathrm{E}, 457 \mathrm{~m}\right.$ a.s.l.) for study. The growing seasons in 2010 lasted from the planting day of DOY 116 to the harvesting day of DOY 273 for potato (26 April to 30 September 2010), and DOY 144 (transplanting day) to DOY 290 (harvesting day) for rice (24 May to 17 October 2010). Normally potatoes are harvested at the end of August. However, intensive rain events during summer 2010 postponed the harvesting 15 day to one month later than usual.

An eddy-covariance system was alternately running above the potato field or the nearby rice field for, in total, three periods at each field site. The first period at the potato site started from DOY 152 to 175 , the second from DOY 187 to 203 , and the last period from DOY 225 to 240 . In-between the eddy-covariance system was moved to the rice field site (periods over rice from DOY 177 to 186,203 to 223 and 242 to 274). The turbulence fluxes of momentum, heat, $\mathrm{H}_{2} \mathrm{O}$ and $\mathrm{CO}_{2}$ were measured on a mast $2.5 \mathrm{~m}$ above ground at the potato field and $2.8 \mathrm{~m}$ at the rice field, using an ultrasonic anemometer (USA-1, Meteorologische Messtechnik $\mathrm{GmbH}$, Germany) and a fast-response open-path $\mathrm{H}_{2} \mathrm{O} / \mathrm{CO}_{2}$ analyzer (LI-7500, LI-COR Inc., USA). The software package TK3 (Mauder and Foken, 2011), developed by the Department of Micrometeorology, University of Bayreuth, Germany, post-processed and corrected high frequency
BGD

9, 2883-2919, 2012

\section{Daytime net ecosystem exchange of carbon dioxide \\ P. Zhao and J. Lüers}

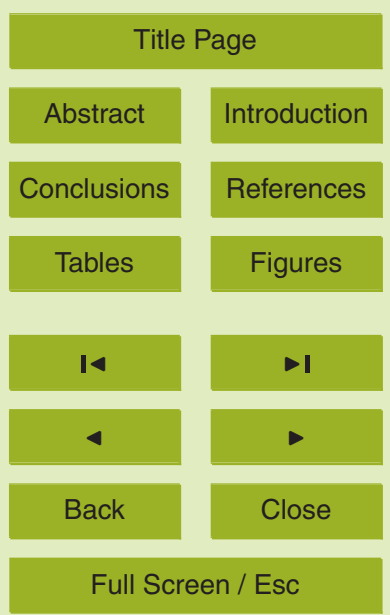

Printer-friendly Version

Interactive Discussion 
$(20 \mathrm{~Hz})$ raw data to calculate 30 -min aggregated fluxes of NEE and sensible and latent heat and generate the observed database (Database-observation). This flux calculating and correcting strategy is well documented, inter-compared by the international micrometeorology community (Mauder et al., 2008), and successfully applied during 5 known major field experiments such as EBEX-2000 (Mauder et al., 2007, Oncley et al., 2007), LITFASS-2003 (Mauder et al., 2006), and COPS-2007 (Eigenmann et al., 2011).

Automatic weather stations (AWS, WS-GP1, Delta-T Devices Ltd., UK) were used at both sites for the measurement of meteorological variables (5-min values), including air temperature, humidity, wind speed and direction, precipitation, and global radiation.

Biomass samples were collected and measured half-monthly at both sites. On each occasion, five to ten whole plants were randomly sampled and immediately separated manually into leaves, dead parts, stems, and roots. Leaf areas were measured by a leaf area meter (LI-3000A, LI-COR Inc., USA) to calculate the Leaf Area Index (LAI). A

15 linear interpolation between the measured LAI values was used to produce a complete time series.

For further information about the field campaign, see Zhao et al. (2011).

\subsection{Generation of high-quality database}

\subsubsection{Quality flags}

20 To get an impression about the quality of the calculated 30-min flux values, standardized tests should be applied to determine if the assumptions required by the eddycovariance technique are fulfilled or not. We used the overall quality classification system including steady-state test (trend conditions) and the integral turbulence characteristics test (to test the development of turbulent conditions) following Foken and Wichura (1996) and Foken et al. (2004) to mark low quality NEE data. Ruppert et al. (2006) suggest that these tests have the advantage over a friction velocity threshold criterion (Golden et al., 1996) for a flux data quality assessment, because the rejection
BGD

9, 2883-2919, 2012

\section{Daytime net ecosystem exchange of carbon dioxide \\ P. Zhao and J. Lüers}

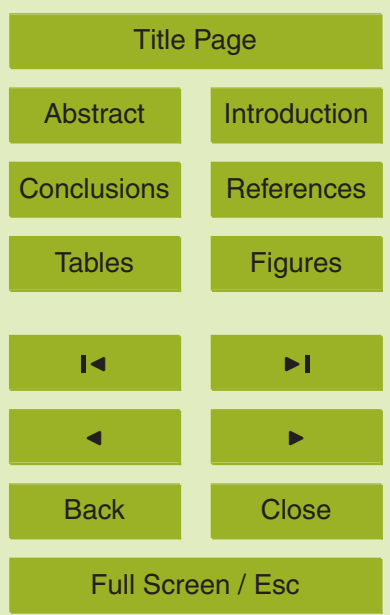

Printer-friendly Version

Interactive Discussion 
of data by these tests is less restrictive, which leads to an increase of the number of valid data usable for parameterization, especially during nighttime and summer.

\subsubsection{Footprint analysis}

A footprint analysis was performed using a Lagrangian stochastic forward model to 5 estimate two-dimensional contributions of source areas (Rannik et al., 2000; Göckede et al., 2004). As the model computation times are high, source weight functions for halfhourly measurements were picked from pre-calculated tables following a procedure used in Göckede et al. (2004, 2006, and 2008). The footprint model shows that both the target potato field and rice field contributed more than $95 \%$ of the related area in unstable and neutral stratification conditions. In stable conditions the eddy-covariance measurement at the potato field was slightly influenced by the adjacent cabbage field, which could be ignored in our case.

\subsubsection{Instrument status}

The eddy-covariance system is disturbed by rain and fog events and therefore produces 15 an unreliable observation. It is suggested that information from a Present Weather Detector (synoptic weather code) and/or a diagnostic or status signal e.g. from the gasanalyzer, if available, can be used to determine these periods (Ruppert et al., 2006). In our study, besides using humidity and precipitation records from the AWS to determine the rain and fog events, we used all of the diagnostic signals from LI-7500 digital outputs, including the AGC values, the status of the chopper motor and the chopper temperature controller, the detector cooler, and the sync between the LI-7500 embedded software and the chopper motor, to determine the periods when the gas analyzer was untrustworthy. We found that the rain or fog periods determined by the nearby weather station and the untrustworthy periods determined by the diagnostic signals were all included in the periods when AGC-values were over or below the instrument specific baseline, i.e. 50 in this study. Therefore, all the periods in question could be
BGD

9, 2883-2919, 2012

\section{Daytime net ecosystem exchange of carbon dioxide \\ P. Zhao and J. Lüers}

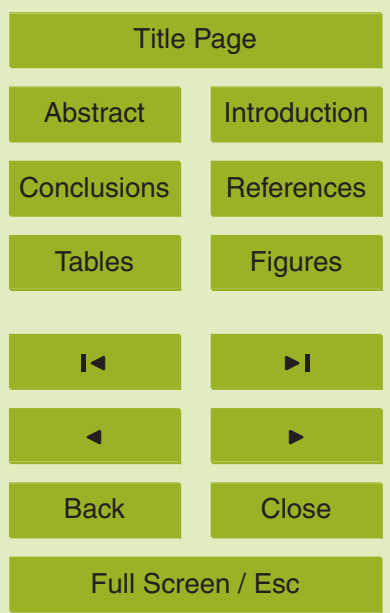

Printer-friendly Version

Interactive Discussion 
detected by just a simple check of whether the AGC is unequal to the instrument's baseline. NEE data obtained during these disturbed periods were marked as being low quality.

\subsubsection{New Multi-Step Error Filter}

5 In addition to the spike detection applied to the high frequency data ( $10 \mathrm{~Hz}$ to $30 \mathrm{~Hz})$ implemented in the eddy-covariance software package and considering the suggestion by Papale et al. (2006), we developed the expanded Multi-Step-Error-Filter algorithm to statistically examine aggregated time series of flux and meteorological data in general. The filter is designed to search for outliers or inhomogeneities, or to separate, for ex-

10 ample, 30-min data values accordingly to a quality classification or to distinct weather conditions. The user can choose from six steps:

1. All of the already addressed incorrect values from the eddy-covariance software package (in our case the TK3) or any other pre-data-processing software (e.g. data-loggers) will be inherited.
2. All direct measurements (e.g. horizontal wind speed, vertical wind speed after rotation, sonic temperature, absolute humidity, $\mathrm{CO}_{2}$ or other trace gas concentrations) and subsequently all derived parameter (covariances, wind direction, atmospheric stability, and all fluxes) will be filtered applying reasonable physical consistency limits adjustable for each parameter.

3. As the next step, a quality classification (flag-system) of (1) the derived fluxes determined by any eddy-covariance software package or (2) meteorological data of interest can be used to eliminate certain quality classes. We used the Foken and Wichura (2006) quality classification and the TK3 software package for the flux data (see Sect. 2.2.1).

4. As an option, a Status-or-Threshold-Value (STV) filter can be used to separate or mark certain periods. This could be, for example, information from a Present 2890
BGD

9, 2883-2919, 2012

\section{Daytime net ecosystem exchange of carbon dioxide \\ P. Zhao and J. Lüers}

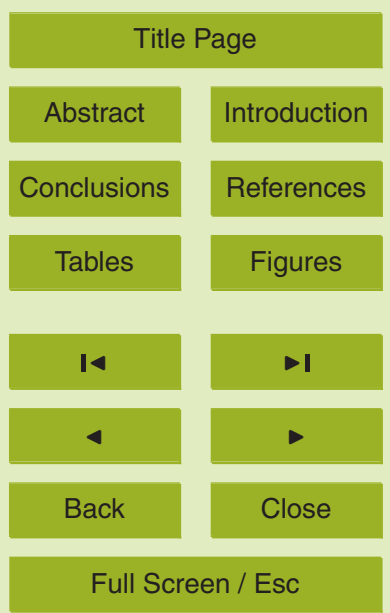

Printer-friendly Version

Interactive Discussion 
Weather Detector (to detect rain or snow periods), a wind speed/direction classification, a footprint information (e.g. percentage of the target area), or a diagnostic value like the combined AGC-value of the LI-7500 used in this study (see Sects. 2.2.2 and 2.2.3)

5. After steps (1) to (4), a statistical outlier check is available, calculating a time series of absolute deviations (with adjustable window size) for each direct measurement and for the derived fluxes, which is then used to run a quantile check to detect major outliers and finally followed by a standard deviation filter (both with adjustable window size and multiplying factor as thresholds for a weaker or stronger filtering).

6. As an option, the detected single or double outliers can be directly gap-filled using a short window linear interpolation. For our purpose of producing a high-quality dataset to test the different parameterization methods, we did not use this option in this study.

Database-observation excluding low quality data and outliers by the Multi-Step Error Filter is used as the high-quality database (Database-high-quality). The final data coverage of Database-high-quality is $71 \%$ for the potato field and $53 \%$ for the rice field during the measurement periods. For the potato field, the data gaps cover $1 \%$ because of the power failure, $21 \%$ by the AGC-check, $3 \%$ by eliminating low-quality classified data, and $4 \%$ by applying the statistical outlier check. For the rice field, this distribution is only slightly different $(7 \%, 30 \%, 2 \%$, and $2 \%$, respectively).

\subsection{Gap-filling methods}

\subsubsection{Database for gap-filling}

Database-high-quality was separated into daytime data and nighttime data by the evaluation of global radiation with a threshold of $20 \mathrm{~W} \mathrm{~m}^{-2}$ and cross-checked against sunrise and sunset time derived from the local time and standard sun-geometrical routines 2891

\section{BGD}

9, 2883-2919, 2012

\section{Daytime net ecosystem exchange of carbon dioxide \\ P. Zhao and J. Lüers}



Printer-friendly Version

Interactive Discussion 
(Reichstein et al., 2005; Papale, 2006; Lasslop et al., 2010). The daytime and nighttime data were used for the test of the different parameterizations, which will be described in the following sections. All the regressions in this study use the "R" software environment (R Development Core Team, 2010). The signs follow the conventional meteoro5 logical definitions that carbon uptake by the ecosystem is negative and carbon release is positive.

\subsubsection{Ecosystem respiration $\left(R_{\mathrm{eco}}\right)$ estimate}

The Lloyd-Taylor function (Lloyd and Taylor, 1994; Falge et al., 2001; Ruppert et al., 2006) was used for parameterization of the temperature dependence of $R_{\text {eco }}$ :

$10 R_{\mathrm{eco}}=R_{\mathrm{ref}} e^{E_{0}\left(\frac{1}{T_{\mathrm{ref}}-T_{0}}-\frac{1}{T-T_{0}}\right)}$,

where $R_{\text {ref }}\left(\mu \mathrm{mol} \mathrm{m}{ }^{-2} \mathrm{~s}^{-1}\right)$ is the ecosystem respiration rate at a reference temperature $\left(T_{\text {ref }}\right.$, set as $\left.283.15 \mathrm{~K}\right), E_{0}(\mathrm{~K})$ is the temperature sensitivity, $T(\mathrm{~K})$ is the air temperature instead of unavailable soil temperature, and $T_{0}(\mathrm{~K})$ is a constant value of $227.13 \mathrm{~K}$ as in Lloyd and Taylor (1994).

15 Assuming no photosynthesis during nighttime (Reichstein et al., 2005), the measured nighttime NEE is $R_{\text {eco }}$. The nighttime data in Database-high-quality was used for the parameterization of Eq. (1). The fitted parameters and daytime temperature were used to calculate the daytime $R_{\text {eco }}$.

\subsubsection{Parameterization for the plant's light response function}

\section{Conventional schemes (temperature or time-window binning scheme)}

Light response functions describe the solar radiation dependency of NEE. As the rectangular hyperbolic function shows the best overall performance among many light response functions used for daytime NEE gap-filling (Falge et al., 2001), the gap-filling
BGD

9, 2883-2919, 2012

\section{Daytime net ecosystem exchange of carbon dioxide \\ P. Zhao and J. Lüers}

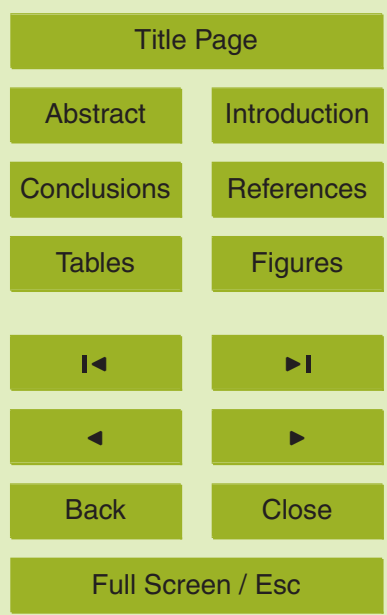

Printer-friendly Version

Interactive Discussion 
methods in this study are on the basis of the Michaelis-Menten function (Michaelis and Menten, 1913)

$\mathrm{NEE}=\frac{\alpha R_{\mathrm{g}} \beta}{\alpha R_{\mathrm{g}}+\beta}+R_{\mathrm{eco}}$,

where $R_{\mathrm{g}}\left(\mathrm{W} \mathrm{m}^{-2}\right)$ is the global radiation, $\alpha\left(\mu \mathrm{mol} \mathrm{s}^{-1} \mathrm{~W}^{-1}\right)$ is the initial slope of the 5 curve, and $\beta\left(\mu \mathrm{mol} \mathrm{m}{ }^{-2} \mathrm{~s}^{-1}\right)$ is the saturated $\mathrm{CO}_{2}$ uptake rate when $R_{\mathrm{g}}$ is close to infinity.

Normally, the parameterization for Eq. (2) can be improved by a temperature binning scheme (binning observations into temperature classes) to capture the temperature dependence of the carbon assimilation (Falge et al., 2001; Ruppert et al., 2006), or by a time-window scheme (binning observations into time intervals) to distinguish different seasonal response within different periods (Falge et al., 2001; Moffat et al., 2007). Different opinions, however, exist in the community about the utilization of these schemes. The temperature binning scheme is based on the fact that the assimilation of $\mathrm{CO}_{2}$ has an optimal temperature, below or above which the photosynthesis ability will decrease 15 (Saxe et al., 2001). Nevertheless, it is found that air temperature has weak influence on photosynthesis during summer in forests (Bassow and Bazzaz, 1998). The timewindow scheme is based on the seasonal changes in leaf area, soil moisture and photosynthetic capacity, which lead to the requirement of continual updating and adjusting of the regression scheme (Baldocchi, 2003). The selection of time windows is empirical and varying from one month to a full year for forest sites (Falge et al., 2001; Stoy et al., 2006; Moffat et al., 2007). For grassland, the use of a 5-day moving window to capture the rapid change of the surfaces is reported (Ammann et al., 2007). A short time window of 4 to 15 days is normally used to account for seasonal parameter variability (Lasslop et al., 2010). Generally, the widths of time windows for regression depend on both (1) how rapidly the vegetation develops, and (2) how large the gaps are because the time-window scheme cannot fill gaps larger than the selected time window (Falge

BGD

9, 2883-2919, 2012

\section{Daytime net ecosystem exchange of carbon dioxide}

P. Zhao and J. Lüers

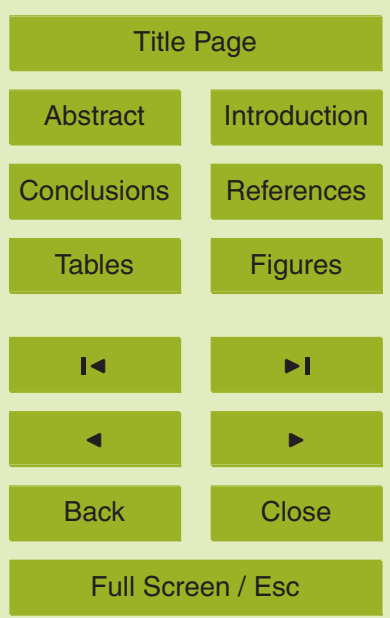

Printer-friendly Version

Interactive Discussion 
et al., 2001; Stoy et al., 2006), which could be a problem for sites which are often influenced by power failure or bad weather. It is reported, however, that additional temporal sub-binning of data did not significantly improve the simulation of temperature binning scheme for forest sites (Ruppert et al., 2006). In this study, Database-high-quality were 5 binned into $14 \mathrm{~K}, 8 \mathrm{~K}, 4 \mathrm{~K}$, or $2 \mathrm{~K}$ temperature classes, or sorted into 16-day, 8-day, 4day, or 2-day time windows, to test the temperature and seasonal dependencies of the parameterization of Eq. (2). Individual fittings of $\alpha$ and, $\beta$ were determined for each temperature class or time window.

A VPD factor was introduced to account for the stomatal response to dry air condi10 tions. Equation (2) was modified by introducing an exponential function (Lasslop et al., 2010)

$\beta^{*}=\left\{\begin{array}{cl}\beta_{0}^{*} e^{-k\left(\mathrm{VPD}-\mathrm{VPD}_{0}\right)}, & \mathrm{VPD}>\mathrm{VPD}_{0} \\ \beta_{0}^{*} & , \mathrm{VPD} \leq \mathrm{VPD}_{0},\end{array}\right.$

where the threshold $\mathrm{VPD}_{0}(\mathrm{hPa})$ was set to $10 \mathrm{hPa}$ (Lasslop et al., 2010).

\section{New scheme (Leaf Area Index factor scheme)}

15 As carbon exchange between agro-ecosystems and the atmosphere is strongly correlated to crop development (Béziat et al., 2009), and LAl plays a key role in the allocation of carbon to leaves (González-Sanpedro et al., 2008), our new scheme for seasonal response introduces a LAI factor to account for seasonal variability. As NEE is the balance between $R_{\text {eco }}$ and the gross primary productivity (GPP),

$20 \mathrm{NEE}=\mathrm{GPP}+R_{\mathrm{eco}}$,

from Eqs. (2) and (4) we obtain
BGD

9, 2883-2919, 2012

\section{Daytime net ecosystem exchange of carbon dioxide \\ P. Zhao and J. Lüers}

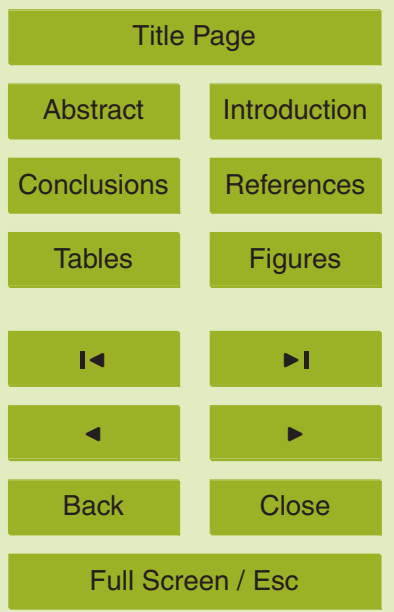

Printer-friendly Version

Interactive Discussion 
$\mathrm{GPP}^{\prime}=\frac{\mathrm{GPP}}{\mathrm{LAl}}$

BGD

$\alpha^{\prime}=\frac{\alpha}{\mathrm{LAl}}$

5 and

$\beta^{\prime}=\frac{\beta}{\mathrm{LAl}}$,

the combined Eqs. (5) to (8) result in Eq. (9)

$\mathrm{GPP}^{\prime}=\frac{\alpha^{\prime} R_{\mathrm{g}} \beta^{\prime}}{\alpha^{\prime} R_{\mathrm{g}}+\beta}$,

where GPP', $\alpha^{\prime}$, and $\beta^{\prime}$ are normalized GPP, $\alpha$, and $\beta$, respectively. We assume that green leaves per unit area have identical photosynthesis ability even during different growing stages. Therefore, NEE in the whole Database-high-quality would obey Eq. (9) and can be used for parameterization of the LAl-factor scheme.

\subsubsection{Evaluations of the methods}

To assess the agreement between the observation and the simulation by the fitted parameters, a random walk was performed along Database-high-quality to mark $10 \%$ of them as artificial gaps (Database-artificial-gaps) (Moffat et al., 2007). The remaining $90 \%$ of Database-high-quality were used to fit the equations of the models in question (Database-parameterization). The gap-filling methods were evaluated by examining the comparison between the simulation (Database-simulation) and Database-artificial-

\section{Daytime net ecosystem exchange of carbon dioxide}

P. Zhao and J. Lüers

Title Page

Abstract

Introduction

Conclusions

References

Tables

Figures

14

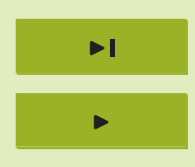

Back

Close

Full Screen / Esc

Printer-friendly Version

Interactive Discussion 
disadvantages for assessing the goodness-of-fit of model simulations (Legates and McCabe, 1999), we evaluated the overall performance of these methods by ranking Nash-Sutcliffe model efficiency coefficient (NSeff) and index of agreement $(d)$ between Database-simulation and Database-artificial-gaps. Additionally, mean average error (MAE), standard deviation (SD), root mean square error (RMSE), and normalized root mean square error (NRMSE) were also calculated to indicate the magnitude and distribution of the individual errors.

We used Taylor diagrams (Taylor, 2001) to plot SD, $R$, and NRMSE of the agreement between Database-simulation and Database-artificial-gaps in one figure in order 10 to test the sensitivity of a gap-filling scheme. In a Taylor diagram, each single point specifies the performance of one scheme, with the radial distance as SD, the polar angle as $R$, and distance to observation point as NRMSE. A farther distance between two simulations indicates a bigger sensitivity.

\section{Results and discussion}

\section{3.1 Meteorological conditions and biomass development}

The meteorological conditions and biomass development during the growing seasons are shown in Fig. 1. As both of our research sites were close to each other, the meteorological conditions were quite similar. Therefore, only those at the potato field are shown. Daily mean temperatures at both sites varied from $8^{\circ} \mathrm{C}$ to $27^{\circ} \mathrm{C}$ during the growing seasons, which occupied a more narrow range than normal temperature records covering a whole year. The relative humidity was often high, resulting in many fog events. The Asian monsoon and subsequent typhoons brought many rain events during July, August, and September, resulting in a decrease of solar radiation. Large gaps (several days) in Database-parameterization were found during these rain events owing to the

\section{BGD}

9, 2883-2919, 2012

\section{Daytime net ecosystem exchange of carbon dioxide \\ P. Zhao and J. Lüers}

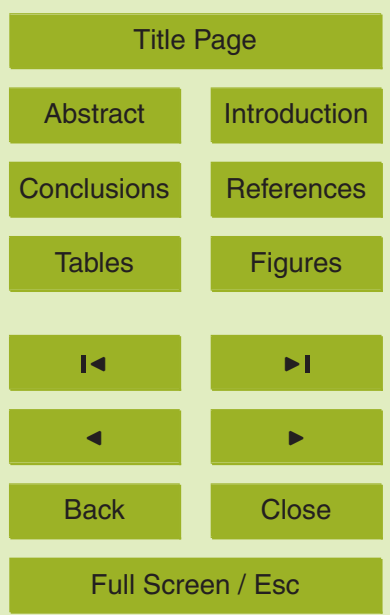

Printer-friendly Version

Interactive Discussion 
$\mathrm{LAI}$ is $0.14 \mathrm{~m}^{2} \mathrm{~m}^{-2}$ per day at the potato field, and $0.06 \mathrm{~m}^{2} \mathrm{~m}^{-2}$ per day at the rice field during the period.

BGD

\subsection{Conventional time-window scheme}

The performances of simulations applying the conventional time-window scheme for 5 daytime NEE simulation are shown in Fig. 2. The time-window scheme apparently improves the agreement between the simulation and the observation, with high indexes of agreements up to 0.98 and NSeff up to 0.93 . The simulation is very sensitive when the time window is decreased from 90 days to 8 days. No difference in sensitivity between the time windows of 8-day, 4-day, and 2-day is shown either in Fig. 2 or by the 10 index of agreement, or NSeff. For the potato field, however, we found that a 4-day time window is as good as a 2-day and better than an 8-day window because the mean average error is $2.2 \mu \mathrm{mol} \mathrm{m}^{-2} \mathrm{~s}^{-1}$ (8-day), $1.9 \mu \mathrm{mol} \mathrm{m} \mathrm{m}^{-2} \mathrm{~s}^{-1}$ (4-day), and $1.9 \mu \mathrm{mol} \mathrm{m}^{-2} \mathrm{~s}^{-1}$ (2-day). For the rice field, 8-day, 4-day and 2-day time windows perform similarly, with identical mean average errors of $1.6 \mu \mathrm{mol} \mathrm{m}^{-2} \mathrm{~s}^{-1}$. The 2-day time window performs 15 even a little worse than the 4-day time window at the rice field owing to the insufficient data coverage. Therefore, the best time window is 4-day for the potato field and 8-day for the rice field. If we consider the mean change rate of $L A I$, then we find that the change of LAl $(\triangle \mathrm{LAl})$ within these best time windows is approximately $0.5 \mathrm{~m}^{2} \mathrm{~m}^{-2}$. The simulations are not sensitive to the widths of time windows when $\Delta \mathrm{LAl}<0.5 \mathrm{~m}^{2} \mathrm{~m}^{-2}$. 20 Therefore, this value of $\Delta \mathrm{LAl}$ could be used as an indicator to determine the width of the best time windows for inter-site comparison and even for other types of croplands, which needs further investigation.

\subsection{Performance of LAl-factor scheme}

The simulation of the LAl-factor scheme according to Eqs. (4) to (9) shows a good 25 agreement with the observation, with an index of agreement of 0.93 for the potato field and 0.87 for the rice field. This good performance indicates that the LAl-factor scheme
9, 2883-2919, 2012

\section{Daytime net ecosystem exchange of carbon dioxide \\ P. Zhao and J. Lüers}

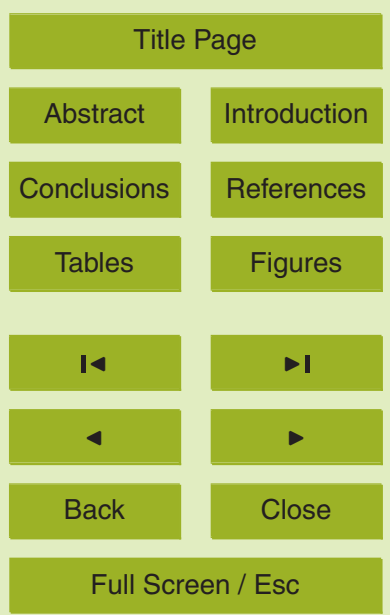

Printer-friendly Version

Interactive Discussion 
could be used as a new method to parameterize the light response of crops as well as an alternative method to the time-window scheme to capture the seasonal change of the vegetation and surface conditions.

As both the conventional time-window scheme and the LAl-factor scheme can cap5 ture the growing stages of the crops, we compared the fitted parameters - the initial slope $(\alpha)$ and the saturated GPP $(\beta)$ - of the time-window scheme with those of the LAl-factor scheme (Fig. 3), to demonstrate the acceptability of the latter. The scattering of the points for the rice field in Fig. 3, however, possibly indicates some errors made by the LAl estimation. As one of the most important biophysical variables, LAl plays a key 10 role in photosynthesis (Jiang et al., 2010). During the mid seasons when LAI is large, the overlapping of green leaves results in less efficient photosynthesis than during the early and late seasons, which makes the estimated mid-season LAI larger than the efficient LAI (so called foliar clumping effect). This is the reason why $\alpha^{\prime}$. LAI and $\beta^{\prime}$. LAI are overestimated (more negative) during the mid-season and underestimated (more positive) during the early and late seasons. Another possible reason is that diffuse radiation is more efficient for carbon assimilation than direct radiation (Granier et al., 2000; Xing et al., 2007). The time-window scheme separates cloudy days from clear days to a certain degree, while the LAl-factor scheme mixes them together.

The LAI-factor scheme has the following advantages, conferred by using the whole

\section{Database-parameterization without any grouping instead of divided time-series:}

1. Conventional gap-filling methods suffer from a lack of data in each data class, if the width of time windows or temperature classes (mean diurnal variance method and non-linear regression method) or the width of the cells (look-up table method) does not match the statistical data distribution. The conflict exists in the requirement for a time-window to be short enough to exclude the errors contained in the nonlinear dependence of environmental variables (Falge et al., 2001) and to be long enough to contain sufficient data for calculating a meaningful statistic needed to apply the mean diurnal variance method, the look-up table method,

\section{BGD}

9, 2883-2919, 2012

\section{Daytime net ecosystem exchange of carbon dioxide}

P. Zhao and J. Lüers

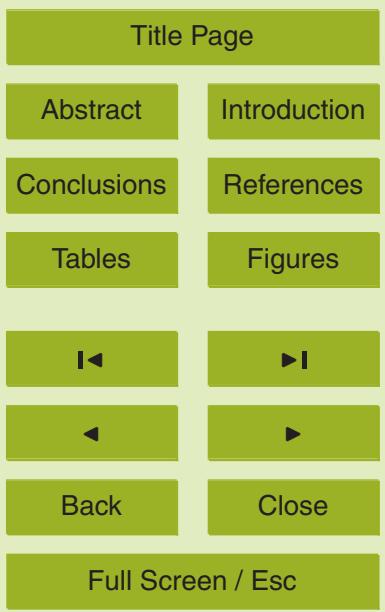

Printer-friendly Version

Interactive Discussion 
or the non-linear regression method. This statistical problem can be avoided by using the LAl-factor scheme.

BGD

2. The time-window related schemes have difficulties if large gaps exist, and do not work when the period of the missing data is longer than the time-window itself (Stoy et al., 2006). These cases often occur due to the power failure at the locations of field campaigns or during longer rain or fog events e.g. in the monsoon and subsequent typhoon season in South Korea. If the LAl during these large times without direct flux measurements is available and if it delivers information about the crop development, the LAl-factor scheme can be included into the light response function to fill the missing data.

The performance of the LAl-factor scheme strongly depends on the estimation of the LAI itself. Incorrect values are a source of discrepancy between simulated and observed NEE. The errors could result from:

1. The sampling. In our case, every measured LAI-value was estimated from 5 to 10 randomly sampled plants in the footprint-area of the eddy-covariance measurement of both field sites. Since individual plants develop slightly differently from each other, the limited number of samples could result in an error through the calculation of a representative mean.

2. The interpolation. The simple linear interpolation to fill the time-steps between the distinct LAI measurements could miss some development stage of the plants. LAI normally remains constant at a potato field when the crop is fully developed (González-Sanpedro et al., 2008). Unfortunately, the limitations of the field campaign provide a sparse LAI curve with only one measurement at the peak during the mid-season stage (Fig. 1). Thus, the linear interpolation will probably under-
9, 2883-2919, 2012

\section{Daytime net ecosystem exchange of carbon dioxide}

P. Zhao and J. Lüers

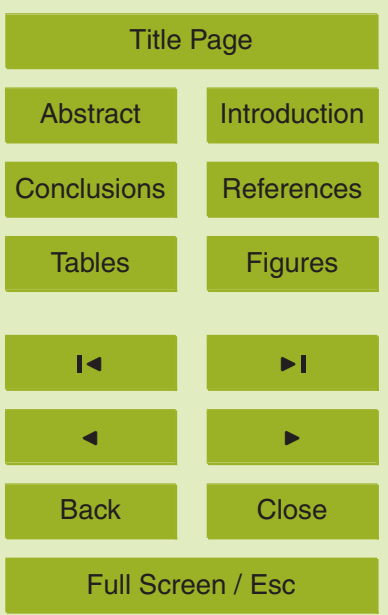

Printer-friendly Version

Interactive Discussion 
3. The efficient LAI. When the plants are fully developed, green leaves partially or totally overlap each other (foliar clumping), which makes the efficient LAI lower than the measured LAI.

These potential errors mentioned above could explain why the simulation of the LAI5 factor scheme is worse than the time-window scheme.

\subsection{Temperature-binning scheme}

The performances of temperature-binning approaches are shown in Fig. 4. All the temperature-binning approaches (class widths between $28 \mathrm{~K}$ and $2 \mathrm{~K}$ ) for the potato field had a poor performance, with low indexes of agreement (less than 0.72) and low

(less than 0.32). The consequently reduc the explained variance for NEE for the potato field, which proves a poor sensitivity of the potatoes to temperature. But for the rice field, the index of agreement increased from 0.61 to 0.85 and the NSeff from 0.16 to 0.58 , decreasing the width of the temperature bins from $28 \mathrm{~K}$ to $8 \mathrm{~K}$, which superficially indicates a better temperature sensitivity 15 of the rice.

For both sites, the smaller classes of $8 \mathrm{~K}, 4 \mathrm{~K}$ and $2 \mathrm{~K}$ have a similar performance, indicating that it is unnecessary to bin the data into temperature classes smaller than $8 \mathrm{~K}$. This range is larger than the $4 \mathrm{~K}$ temperature classes used by Falge et al. (2001) for a variety of sites including croplands and the $2 \mathrm{~K}$ temperature classes used by Ruppert et al. (2006) for a forest site. They also reported that additional time windows do not significantly improve the temperature binning method, because the existing long-time seasonal temperature response of the long-living and slow-growing coniferous forest is already covered by the time-independent allocation of the values into the temperature bins. But this cannot work for short-living and fast-growing crops, thus we found that the temperature-binning scheme and time-window scheme perform differently in our study. Either the LAl-factor scheme or the time-window scheme, even with the 16-day time-window approach, results in a much better agreement than the smallest
BGD

9, 2883-2919, 2012

\section{Daytime net ecosystem exchange of carbon dioxide \\ P. Zhao and J. Lüers}

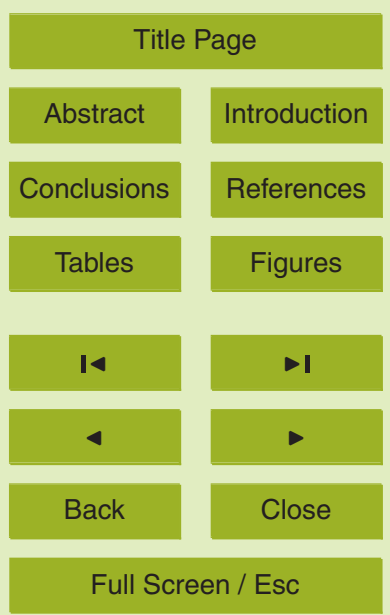

Printer-friendly Version

Interactive Discussion 
temperature binning $(2 \mathrm{~K})$ approach. This implies that - if the seasonal or daily weather conditions are in a normal climate range - the long-time seasonal and short time diurnal temperature response of the crops play a minor role compared to the fast changing development stages $\left(\mathrm{CO}_{2}\right.$-accumulation ability expressed, for example, by the $\left.\mathrm{LAI}\right)$ of 5 the crop plant.

Furthermore, we combined the LAl-factor scheme with the temperature binning approach. We found that additional temperature binning does not improve the simulation of the LAl-factor scheme (not shown), which demonstrates that the temperature dependency can be ignored if the plant development is well considered.

10 The temporal distribution within temperature classes (Fig. 5) could explain why a smaller temperature binning could improve the simulation for both sites in spite of the minor temperature dependency. Some temperature values were observed only during some special periods. For instance, the 2 to $10^{\circ} \mathrm{C}$ temperature class at the potato field falls exactly into the DOY 144 to 160 time window, which makes the overall simulation of $8 \mathrm{~K}$ temperature binning approach better than the simulation of larger temperature classifications. Since the 18 to $26^{\circ} \mathrm{C}$ temperature class is distributed over almost the whole growing season, the temperature binning scheme mixes these time windows together and fails to perform a good simulation.

Generally speaking, temperature binning contains some, but not all, relevant information of seasonal response for NEE gap-filling for croplands, which is insufficient for the regression of the light response function. The air temperature has both a diurnal and a seasonal cycle within a year. As the diurnal cycle of temperature is partly a function of solar radiation, which is included in the light response function, and the seasonal cycle of temperature is contained in the time-window scheme or the LAl-factor scheme, we suggest that temperature binning could be ignored if the plant development is well simulated.

\section{BGD}

9, 2883-2919, 2012

\section{Daytime net ecosystem exchange of carbon dioxide}

P. Zhao and J. Lüers

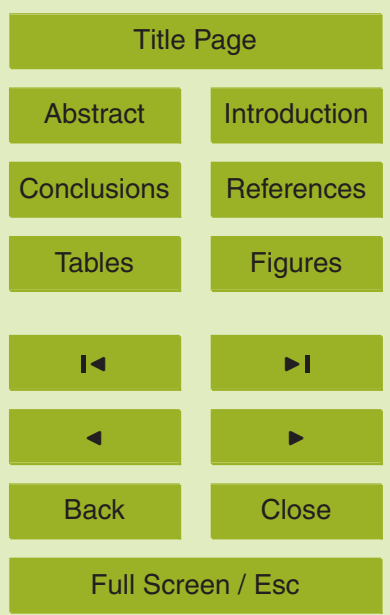

Printer-friendly Version

Interactive Discussion 


\subsection{VPD factor}

According to Eq. (2) the NEE must have the same diurnal pattern as the solar radiation if the development of the vegetation is ignored. However, an asymmetric pattern occurred in the diurnal cycle of NEE, i.e. the peak of NEE appears before noon. This 5 can be explained by the fact that in the afternoon higher temperature and higher VPD leads to a higher evaporation rate and then to a stomatal closure (Lasslop et al., 2010). That will decrease the NEE significantly. We used the time-window scheme including a VPD-factor to test this effect at croplands. The mean diurnal cycle of the VPD, solar radiation, and observed and simulated NEE shows that the role that VPD plays on

10 NEE at the rice field during the whole growing season can be ignored (Fig. 6b). This is unsurprising, because with the permanently irrigated and flooded rice terraces, the observed VPD is below the plant physiological threshold $\left(\mathrm{VPD}_{0}=10 \mathrm{hPa}\right)$ during most of time of the growing season (Fig. 7).

Unexpected is that the use of the VPD-factor in Eq. (3) for the potato field does not, 15 however, improve the simulation, although the mean VPD is above the threshold of $10 \mathrm{hPa}\left(\mathrm{VPD}_{0}\right)$ in most hours during the daytime (not shown). The explanation in our case is that such a high VPD was only observed during the first observation period from DOY 152 to 175 (Fig. 7) when the monsoon had not yet started, especially in the afternoon when the VPD exceeded $15 \mathrm{hPa}$ (Fig. 6a), caused by dry weather and lack of plant transpiration (dry bare soil or only less-developed vegetation). These high VPD values at this short early period after planting with a high percentage to bare soil contributed significantly to the average of the whole growing season, but the effect to the NEE can be ignored because the $\mathrm{CO}_{2}$-fluxes and thus the exchange were very small. The result is the asymmetric pattern between VDP and NEE. When the monsoon started and the vegetation was developed enough, the VPD decreased below VPD ${ }^{-}$ threshold resulting in a symmetric diurnal pattern of the NEE in the following summer and autumn.
BGD

9, 2883-2919, 2012

\section{Daytime net ecosystem exchange of carbon dioxide}

P. Zhao and J. Lüers

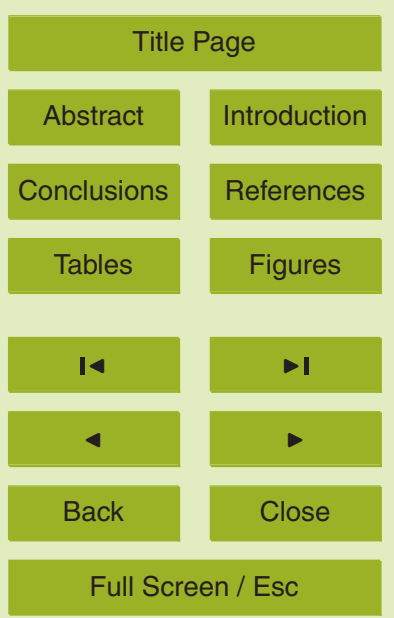

Printer-friendly Version

Interactive Discussion 


\section{Conclusions}

In this research, we were able to show that a different approach is necessary to explain the variation of net ecosystem exchange of $\mathrm{CO}_{2}$ over short-living and fast-growing crop plants, and that this could be done well enough to fill large data gaps to finally obtain 5 seasonal or annual budgets of carbon sequestration or carbon release.

Only a high-quality, error-filtered database should be used as input to the fitting algorithm or regression calculations which are later used to fill the gaps in the original measurements, or to compare the modeled with observed data, not only for testing the efficiency of the varied parameterizations of the plant's light response function (as we have done), but in all cases.

For that reason we defined a fast-working and comprehensible Multi-Step Error Filter procedure to build an error-cleared dataset which includes the averaged energy and matter fluxes and the related basic meteorological and soil-physical measurements, because outliers result in poor parameterizations and, many times, in a convergence failure of the non-linear regression algorithm. The new Multi-Step Error Filter procedure could now solve this problem. We recommend running a "strong" filtering setup to obtain only reliable data for the fitting (even if some possible "good" data are also rejected), if the remaining dataset is still big enough to capture the annual variation. Of course, that dataset should also be used for the fitting of the temperature dependency function (in the narrow sense of $\mathrm{CO}_{2}$-respiration or $\mathrm{CO}_{2}$-release of the soil). A part of the Multi-Step Error Filter procedure (Step 4 in Sect. 2.2.4) is the use of the footprint information. Although the footprint analysis in our study shows a good representation of the target area (potatoes and rice) owing to the careful selection of site locations, we suggest that the separation of observed data influence by other nearby land use types should, in any case, be carefully considered.

After this step we were able to run a statistical sensitivity-study of the conventional and new parameterization methods. Since there is no agreement on a standard gapfilling strategy for NEE in the community, we suggest that a comparison between
BGD

9, 2883-2919, 2012

\section{Daytime net ecosystem exchange of carbon dioxide}

P. Zhao and J. Lüers

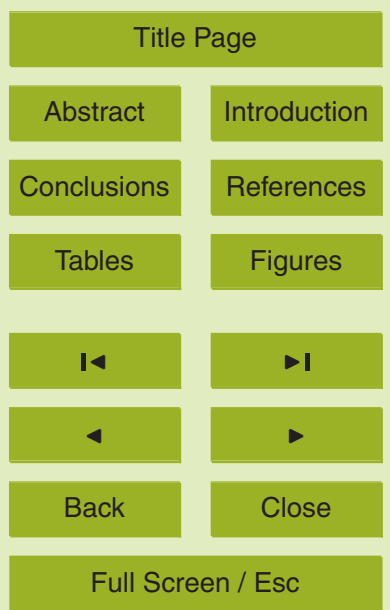

Printer-friendly Version

Interactive Discussion 
observation and simulation using a manipulated dataset - including randomly marked artificial gaps - should be applied and reported together with a gap-filled NEE dataset as a validation of the models in question. We decided to use the Taylor diagrams, together with the Nash-Sutcliffe model efficiency coefficient (NSeff) as an index of agree5 ment, but a mean average error or the root mean square error could also be useful tools to rank the performances of different gap-filling methods.

The seasonal response, especially the fast changing growing stages of crops, cannot be captured by classifying data only into time-independent temperature classes based on the light response function. We were able to prove that the commonly used 10 temperature-binning scheme does not work for such croplands, whether irrigated or not. Therefore, we recommend using instead the conventional time-window scheme together with our new LAI-factor scheme (normalized GPP, Eq. 9). This approach could best parameterize the plants' light response function, solving the problem with the timewindow widths limited by the gap size. These two schemes have the advantages of 15 treating small and large gaps. Therefore, a separation of large and small gaps by determining whether the change of LAl within a gap $(\triangle \mathrm{LAl})$ is larger or smaller than an empirical value, i.e. $0.5 \mathrm{~m}^{2} \mathrm{~m}^{-2}$ in this study, is necessary. This value can also be used to determine the best time-window width. The LAI data is a simple and useful way to explain the NEE seasonal pattern of crops and the related growing stages, which should be included together with energy and matter $\left(\mathrm{H}_{2} \mathrm{O}, \mathrm{CO}_{2}\right)$ flux data, meteorological data, and instrument status data to build up the database of observation. A better estimation of LAI or efficient LAI by a large amount of manual biomass sampling could possibly improve the parameterization of daytime NEE (Sect. 3.3), but this method is destructive and thus could change the footprint of the eddy-covariance measurement. Satellite imaging (González-Sanpedro et al., 2008, resolution of $30 \mathrm{~m}$; Jiang et al., 2010, resolution of $1 \mathrm{~km}$ ), camera retrieving (Migliavacca et al., 2011) or modeling (Li et al., 2011) could be alternatives and expected to reduce these errors and improve the simulation.

The observed VPD response is an unimportant factor, especially in the case of permanent irrigated and/or water flooded rice terraces. In our case the observed VPD was,
BGD

9, 2883-2919, 2012

\section{Daytime net \\ ecosystem exchange of carbon dioxide}

P. Zhao and J. Lüers

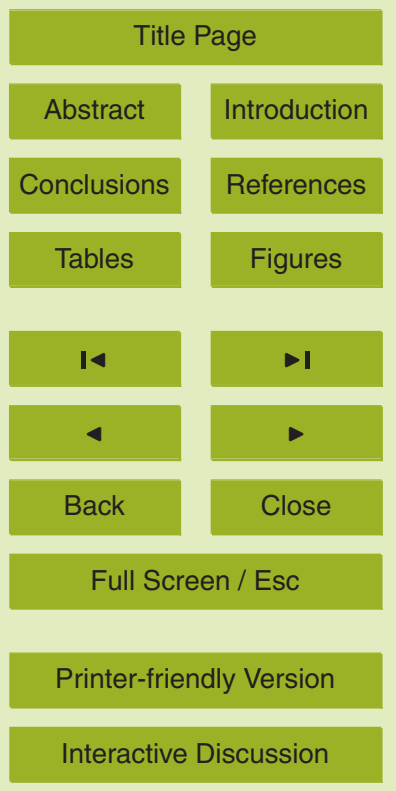


during most of the period of the rice's growing season, below the plant physiological threshold (stomata regulation, Eq. 3). For the non-irrigated agriculture (potato field), the relevance of the VDP depends on the growing stage, the percentage of bare soil and soil humidity and the weather conditions or typical rainy or dry seasons (monsoon or 5 typhoon/hurricane activity or the migration of the Intertropical Convergence Zone and the connected shifting of the poleward atmospheric circulation pattern). In our case, only the early period after the potato planting, with a high percentage of bare soil and a distinct dry spring season in 2010, showed a VPD effect. Since the humidity conditions of non-irrigated croplands are quite site-specific, the VPD-factor should be included together with the LAl-factor scheme and the time-window scheme.

Finally, we defined an overall step-by-step scheme for helping to determine the Net Ecosystem Exchange (NEE) of $\mathrm{CO}_{2}$ of fast-growing croplands, which is presented in Fig. 8.

Acknowledgements. We deeply thank Thomas Foken, Head of the Department of Micromete15 orology, University of Bayreuth, for helpful comments. We also thank John Tenhunen, Chair of the Department of Plant Ecology, University of Bayreuth, for the major support without which this work would not be possible. We are very thankful for the help of all the South Korean and German fellow PhD students, especially Bora Lee and Steve Lindner, during the field operation in Korea. We also appreciate the help given by the colleagues of the Department of Micrometeorology and Department of Plant Ecology, University of Bayreuth. This study was carried out as part of the International Research Training Group TERRECO (GRK 1565/1) funded by the Deutsche Forschungsgemeinschaft (DFG) at the University of Bayreuth, Germany and the Korean Research Foundation (KRF) at Kangwon National University, Chuncheon, South Korea. This publication was also funded by DFG and the University of Bayreuth in the funding program

\section{References}

Ammann, C., Flechard, C., Leifeld, J., Neftel, A. and Fuhrer, J.: The carbon budget of newly established temperate grassland depends on management intensity, Agr. Ecosyst. Environ.,

\section{BGD}

9, 2883-2919, 2012

\section{Daytime net ecosystem exchange of carbon dioxide}

P. Zhao and J. Lüers



Printer-friendly Version

Interactive Discussion 
121, 5-20, 2007.

Baldocchi, D. D.: Assessing the eddy covariance technique for evaluating carbon dioxide exchange rates of ecosystems: past, present and future, Glob. Change Biol., 9, 479-492, 2003.

Baldocchi, D., Falge, E., Gu, L., Olson, R., Hollinger, D., Running, S., Anthoni, P., Bernhofer, C.,

5 Davis, K., Evans, R., Fuentes, J., Goldstein, A., Katul, G., Law, B., Lee, X., Malhi, Y., Meyers, T., Munger, W., Oechel, W., Paw, K. T., Pilegaard, K., Schmid, H. P., Valentini, R., Verma, S., Vesala, T., Wilson, K., and Wofsy, S.: FLUXNET: a new tool to study the temporal and spatial variability of ecosystem-scale carbon dioxide, water vapor, and energy flux densities, B. Am. Meteorol. Soc., 82, 2415-2434, 2001.

10 Bassow, S. L. and Bazzaz, F. A.: How environmental conditions affect canopy leaf-level photosynthesis in four deciduous tree species, Ecology, 79(8), 2660-2675, doi:10.1890/00129658(1998)079[2660:HECACL]2.0.CO;2, 1998.

Béziat, P., Ceschia, E., and Dedieu, G.: Carbon balance of a three crop succession over two cropland sites in South West France, Agr. Forest Meteorol., 149, 1628-1645,

15 doi:10.1016/j.agrformet.2009.05.004, 2009.

Ciais, P., Wattenbach, M., Vuichard, N., Smith, P., Piao, S.L., Don, A., Luyssaert, Sebastiaan, Janssens, Ivan, Bondeau, A., Dechow, R., Leip, A., Smith, P. C., Beer, C., Werf, van der, G. R., Gervois, S., Oost, van, K., Tomelleri, E., Freibauer, A., Schulze, E. D., Carboeurope Synthesis Team: The European carbon balance. Part 2: croplands, Glob. Change Biol., 16, 1409-1428, 2010.

Eigenmann, R., Kalthoff, N., Foken, T., Dorninger, M., Kohler, M., Legain, D., Pigeon, G., Piguet, B., Schüttemeyer, D., and Traulle, O.: Surface energy balance and turbulence network during COPS, Q. J. Royal Meteorol. Soc., 137, 57-69, 2011.

Falge, E., Baldocchi, D., Olson, R., Anthoni, P., Aubinet, M., Bernhofer, C., Burba, G., Ceulemans, R., Clement, R., Dolman, H., Granier, A., Gross, P., Grunwald, T., Hollinger, D., Jensen, N. O., Katul, G., Keronen, P., Kowalski, A., Lai, C. T., Law, B. E., Meyers, T., Moncrieff, H., Moors, E., Munger, J. W., Pilegaard, K., Rannik, U., Rebmann, C., Suyker, A., Tenhunen, J., Tu, K., Verma, S., Vesala, T., Wilson, K., and Wofsy, S.: Gap filling strategies for defensible annual sums of net ecosystem exchange, Agr. Forest Meteorol., 107, 43-69, doi:10.1016/S0168-1923(00)00225-2, 2001.

Foken, T. and Wichura, B.: Tools for quality assessment of surface-based flux measurements, Agr. Forest Meteorol., 78, 83-105, doi:10.1016/0168-1923(95)02248-1, 1996.

\section{BGD}

9, 2883-2919, 2012

\section{Daytime net ecosystem exchange of carbon dioxide}

P. Zhao and J. Lüers

Title Page

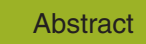

Introduction

Conclusions

References

Tables

Figures

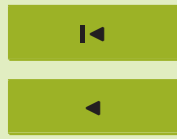

-1

Back

Close

Full Screen / Esc

Printer-friendly Version

Interactive Discussion 
Foken, T., Göckede, M., Mauder, M., Mahrt, L., Amiro, B. D., and Munger, J. W.: Post-field data quality control, Handbook of micrometeorology, 181-208, 2004.

Foley, J. A., Defries, R., Asner, G. P., Barford, C., Bonan, G., Carpenter, S. R., Chapin, F. S., Coe, M. T., Daily, G. C., Gibbs, H. K., Helkowski, J. H., Holloway, T., Howard, E. A., Kucharik,

5 C. J., Monfreda, C., Patz, J. A., Prentice, I. C., Ramankutty, N., and Snyder, P. K.: Global consequences of land use, Science, 309, 570-574, doi:10.1126/science.1111772, 2005.

Gilmanov, T. G., Aires, L., Barcza, Z., Baron, V. S., Belelli, L., Beringer, J., Billesbach, D., Bonal, D., Bradford, J., Ceschia, E., Cook, D., Corradi, C., Frank, A., Gianelle, D., Gimeno, C., Gruenwald, T., Guo, H. Q., Hanan, N., Haszpra, L., Heilman, J., Jacobs, A., Jones, M. B., Johnson, D. A., Kiely, G., Li, S. G., Magliulo, V., Moors, E., Nagy, Z., Nasyrov, M., Owensby, C., Pinter, K., Pio, C., Reichstein, M., Sanz, M. J., Scott, R., Soussana, J. F., Stoy, P. C., Svejcar, T., Tuba, Z., and Zhou, G. S.: Productivity, respiration, and light-response parameters of world grassland and agroecosystems derived from flux-tower measurements, Rangeland Ecology \& Management, 63, 16-39, doi:10.2111/REM-D-09-00072.1, 2010.

Göckede, M., Rebmann, C., and Foken, T.: A combination of quality assessment tools for eddy covariance measurements with footprint modelling for the characterisation of complex sites, Agr. Forest Meteorol., 127, 175-188, doi:16/j.agrformet.2004.07.012, 2004.

Göckede, M., Markkanen, T., Hasager, C. B., and Foken, T.: Update of a footprint-based approach for the characterisation of complex measurement sites, Bound.-Lay. Meteorol., 118, 635-655, 2006.

Göckede, M., Foken, T., Aubinet, M., Aurela, M., Banza, J., Bernhofer, C., Bonnefond, J. M., Brunet, Y., Carrara, A., Clement, R., Dellwik, E., Elbers, J., Eugster, W., Fuhrer, J., Granier, A., Grünwald, T., Heinesch, B., Janssens, I. A., Knohl, A., Koeble, R., Laurila, T., Longdoz, B., Manca, G., Marek, M., Markkanen, T., Mateus, J., Matteucci, G., Mauder, M., Migliavacca, M., Minerbi, S., Moncrieff, J., Montagnani, L., Moors, E., Ourcival, J.-M., Papale, D., Pereira, J., Pilegaard, K., Pita, G., Rambal, S., Rebmann, C., Rodrigues, A., Rotenberg, E., Sanz, M. J., Sedlak, P., Seufert, G., Siebicke, L., Soussana, J. F., Valentini, R., Vesala, T., Verbeeck, H., and Yakir, D.: Quality control of CarboEurope flux data - Part 1: Coupling footprint analyses with flux data quality assessment to evaluate sites in forest ecosystems, Biogeosciences, 5 , $30 \quad$ 433-450, doi:10.5194/bg-5-433-2008, 2008.

Goulden, M. L., Munger, J. W., Fan, S., Daube, B. C., and Wofsy, S. C.: Measurements of carbon sequestration by long-term eddy covariance: methods and a critical evaluation of accuracy, Glob. Change Biol., 2, 169-182, doi:10.1111/j.1365-2486.1996.tb00070.x, 1996.

BGD

9, 2883-2919, 2012

\section{Daytime net ecosystem exchange of carbon dioxide}

P. Zhao and J. Lüers

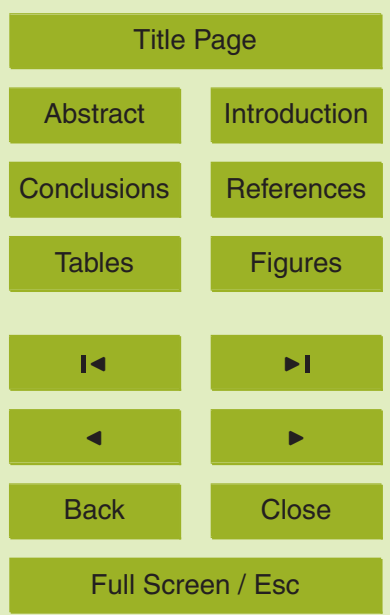

Printer-friendly Version

Interactive Discussion 
González-Sanpedro, M. C., Le Toan, T., Moreno, J., Kergoat, L., and Rubio, E.: Seasonal variations of leaf area index of agricultural fields retrieved from Landsat data, Remote Sens. Environ., 112, 810-824, doi:10.1016/j.rse.2007.06.018, 2008.

Gove, J. and Hollinger, D.: Application of a dual unscented Kalman filter for simultaneous state 5 and parameter estimation in problems of surface-atmosphere exchange, J. Geophys. Res, 111, D08S07, doi:10.1029/2005JD006021, 2006.

Granier, A., Ceschia, E., Damesin, C., Dufrêne, E., Epron, D., Gross, P., Lebaube, S., Ledantec, V., Le Goff, N., Lemoine, D., Lucot, E., Ottorini, J. M., Pontailler, J. Y., and Saugier, B.: The carbon balance of a young Beech forest, Funct. Ecol., 14, 312-325, doi:10.1046/j.13652435.2000.00434.x, 2000.

Greco, S. and Baldocchi, D. D.: Seasonal variations of $\mathrm{CO}_{2}$ and water vapour exchange rates over a temperate deciduous forest, Glob. Change Biol., 2, 183-197, doi:10.1111/j.13652486.1996.tb00071.x, 1996.

Hui, D., Wan, S., Su, B., Katul, G., Monson, R., and Luo, Y.: Gap-filling missing data in eddy 15 covariance measurements using multiple imputation (MI) for annual estimations, Agr. Forest Meteorol., 121, 93-111, doi:10.1016/S0168-1923(03)00158-8, 2004.

Janssens, I. A., Freibauer, A., Ciais, P., Smith, P., Nabuurs, G.-J., Folberth, G., Schlamadinger, B., Hutjes, R. W. A., Ceulemans, R., Schulze, E.-D., Valentini, R., and Dolman, A. J.: Europe's terrestrial biosphere absorbs 7 to $12 \%$ of European anthropogenic $\mathrm{CO}_{2}$ emissions, Science, $20 \quad 300,1538-1542$, doi:10.1126/science.1083592, 2003.

Jiang, B., Liang, S., Wang, J., and Xiao, Z.: Modeling MODIS LAI time series using three statistical methods, Remote Sens. Environ., 114, 1432-1444, 2010.

Kwon, H., Kim, J., Hong, J., and Lim, J.-H.: Influence of the Asian monsoon on net ecosystem carbon exchange in two major ecosystems in Korea, Biogeosciences, 7, 1493-1504, doi:10.5194/bg-7-1493-2010, 2010.

Lasslop, G., Reichstein, M., Papale, D., Richardson, A. D., Arneth, A., Barr, A., Stoy, P., and Wohlfahrt, G.: Separation of net ecosystem exchange into assimilation and respiration using a light response curve approach: critical issues and global evaluation, Glob. Change Biol., 16, 187-208, doi:10.1111/j.1365-2486.2009.02041.x, 2010.

30 Legates, D. R. and McCabe, G. J.: Evaluating the use of "goodness-of-fit" measures in hydrologic and hydroclimatic model validation, Water Resour. Res., 35, 233-241, doi:199910.1029/1998WR900018, 1999.

\section{BGD}

9, 2883-2919, 2012

\section{Daytime net ecosystem exchange of carbon dioxide}

P. Zhao and J. Lüers

Title Page

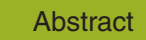

Introduction

Conclusions

References

Tables

Figures

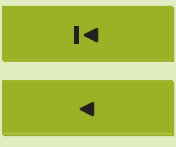

$\rightarrow$

Back

Close

Full Screen / Esc

Printer-friendly Version

Interactive Discussion 
Li, L., Vuichard, N., Viovy, N., Ciais, P., Wang, T., Ceschia, E., Jans, W., Wattenbach, M., Béziat, P., Gruenwald, T., Lehuger, S., and Bernhofer, C.: Importance of crop varieties and management practices: evaluation of a process-based model for simulating $\mathrm{CO}_{2}$ and $\mathrm{H}_{2} \mathrm{O}$ fluxes at five European maize (Zea mays L.) sites, Biogeosciences, 8, 1721-1736, doi:10.5194/bg-81721-2011, 2011.

Lloyd, J. and Taylor, J. A.: On the temperature dependence of soil respiration, Funct. Ecol., 8, 315-323, 1994.

Mauder, M. and Foken, T.: Documentation and instruction manual of the eddy covariance software package TK3, Universität Bayreuth, Abt. Mikrometeorologie, Print, ISSN 1614-8916, 10 Arbeitsergebnisse 46, 2011.

Mauder, M., Liebethal, C., Göckede, M., Leps, J.-P., Beyrich, F., and Foken, T.: Processing and quality control of flux data during LITFASS-2003, Bound.-Lay. Meteorol., 121, 67-88, 2006.

Mauder, M., Oncley, S. P., Vogt, R., Weidinger, T., Riberio, L., Bernhofer, C., Foken, T., Kohsiek, W., DeBruin, H., and Liu, H.: The Energy Balance Experiment EBEX-2000. Part II: Intercomparison of eddy covariance sensors and post-field data processing methods, Bound.-Lay. Meteorol., 123, 29-54, 2007.

Mauder, M., Foken, T., Clement, R., Elbers, J. A., Eugster, W., Grünwald, T., Heusinkveld, B., and Kolle, O.: Quality control of CarboEurope flux data - Part 2: Inter-comparison of eddycovariance software, Biogeosciences, 5, 451-462, doi:10.5194/bg-5-451-2008, 2008.

20 Michaelis, L. and Menten, M.: Die Kinetik der Invertinwirkung, Biochem. Z. 49, 333-369, 1913.

Migliavacca, M., Galvagno, M., Cremonese, E., Rossini, M., Meroni, M., Sonnentag, O., Cogliati, S., Manca, G., Diotri, F., Busetto, L., Cescatti, A., Colombo, R., Fava, F., Morra di Cella, U., Pari, E., Siniscalco, C., and Richardson, A.: Using digital repeat photography and eddy covariance data to model grassland phenology and photosynthetic $\mathrm{CO}_{2}$ uptake, Agr. Forest Meteorol., 151, 1325-1337, doi:10.1016/j.agrformet.2011.05.012, 2011.

Moffat, A. M., Papale, D., Reichstein, M., Hollinger, D. Y., Richardson, A. D., Barr, A. G., Beckstein, C., Braswell, B. H., Churkina, G., Desai, A. R., Falge, E., Gove, J. H., Heimann, M., Hui, D., Jarvis, A. J., Kattge, J., Noormets, A., and Stauch, V. J.: Comprehensive comparison of gap-filling techniques for eddy covariance net carbon fluxes, Agr. Forest Meteorol., 147, $30 \quad$ 209-232, doi:10.1016/j.agrformet.2007.08.011, 2007.

Oncley, S. P., Foken, T., Vogt, R., Kohsiek, W., DeBruin, H., Bernhofer, C., Christen, A., van Gorsel, E., Grantz, D., Feigenwinter, C., Lehner, I., Liebethal, C., Liu, H., Mauder, M., Pitacco, A., Riberio, L., and Weidinger, T.: The Energy Balance Experiment EBEX-2000. Part I:

\section{BGD}

9, 2883-2919, 2012

\section{Daytime net ecosystem exchange of carbon dioxide}

P. Zhao and J. Lüers

Title Page

Abstract

Introduction

Conclusions

References

Tables

Figures

14

$\rightarrow$ I

4

Back

Close

Full Screen / Esc

Printer-friendly Version

Interactive Discussion 
overview and energy balance, Bound.-Lay. Meteorol., 123, 1-28, 2007.

Papale, D.: Data gap filling, in: Eddy Covariance: A Practical Guide to Measurement and Data Analysis, M. Aubinet, T. Vesala and D. Papale (Editors), Springer, Dordrecht, Heidelberg, London, New York, 159-172, 2012.

5 Papale, D. and Valentini, R.: A new assessment of European forests carbon exchanges by eddy fluxes and artificial neural network spatialization, Glob. Change Biol., 9, 525-535, doi:10.1046/j.1365-2486.2003.00609.x, 2003.

Papale, D., Reichstein, M., Aubinet, M., Canfora, E., Bernhofer, C., Kutsch, W., Longdoz, B., Rambal, S., Valentini, R., Vesala, T., and Yakir, D.: Towards a standardized processing of Net Ecosystem Exchange measured with eddy covariance technique: algorithms and uncertainty estimation, Biogeosciences, 3, 571-583, doi:10.5194/bg-3-571-2006, 2006.

R Development Core Team: R: A Language and Environment for Statistical Computing, ISBN 3-900051-07-0, 2010.

Reichstein, M., Falge, E., Baldocchi, D., Papale, D., Aubinet, M., Berbigier, P., Bernhofer, C., 15 Buchmann, N., Gilmanov, T., Granier, A., Grunwald, T., Havrankova, K., Ilvesniemi, H., Janous, D., Knohl, A., Laurila, T., Lohila, A., Loustau, D., Matteucci, G., Meyers, T., Miglietta, F., Ourcival, J.M., Pumpanen, J., Rambal, S., Rotenberg, E., Sanz, M., Tenhunen, J., Seufert, G., Vaccari, F., Vesala, T., Yakir, D., and Valentini, R.: On the separation of net ecosystem exchange into assimilation and ecosystem respiration: review and improved algorithm, Glob.

$20 \quad$ Change Biol., 11, 1424-1439, doi:10.1111/j.1365-2486.2005.001002.x, 2005.

Richardson, A. D. and Hollinger, D. Y.: A method to estimate the additional uncertainty in gapfilled NEE resulting from long gaps in the $\mathrm{CO}_{2}$ flux record, Agr. Forest Meteorol., 147, 199208, doi:10.1016/j.agrformet.2007.06.004, 2007.

Ruppert, J., Mauder, M., Thomas, C., and Lüers, J.: Innovative gap-filling strategy for annual sums of $\mathrm{CO}_{2}$ net ecosystem exchange, Agr. Forest Meteorol., 138, 5-18, doi:10.1016/j.agrformet.2006.03.003, 2006.

Saxe, H., Cannell, M. G. R., Johnsen, Ø., Ryan, M. G., and Vourlitis, G.: Tree and forest functioning in response to global warming, New Phytol., 149, 369-399, doi:10.1046/j.14698137.2001.00057.x, 2001.

30 Stoy, P. C., Katul, G. G., Siqueira, M., Juang, J. Y., Novick, K. A., Uebelherr, J. M., and Oren, R.: An evaluation of models for partitioning eddy covariance-measured net ecosystem exchange into photosynthesis and respiration, Agr. Forest Meteorol., 141, 2-18, 2006.
BGD

9, 2883-2919, 2012

\section{Daytime net \\ ecosystem exchange \\ of carbon dioxide}

P. Zhao and J. Lüers

Title Page

Abstract

Introduction

Conclusions

Tables

References

Figures

14

$\rightarrow 1$

4

Back

Close

Full Screen / Esc

Printer-friendly Version

Interactive Discussion 
Taylor, K. E.: Summarizing multiple aspects of model performance in a single diagram, J. Geophys. Res., 106, 7183-7192, doi:200110.1029/2000JD900719, 2001.

Wu, J., van der Linden, L., Lasslop, G., Carvalhais, N., Pilegaard, K., Beier, C., and Ibrom, A.: Effects of climate variability and functional changes on the interannual variation of the carbon balance in a temperate deciduous forest, Biogeosciences, 9, 13-28, doi:10.5194/bg9-13-2012, 2012.

Xing, Z., Bourque, C. P.-A., Meng, F., Zha, T., Cox, R. M., and Swift, D. E.: A simple net ecosystem productivity model for gap filling of tower-based fluxes: An extension of Landsberg's equation with modifications to the light interception term, Ecol. Modell., 206, 250-262, doi:10.1016/j.ecolmodel.2007.03.031, 2007.

Zhao, P., Lüers, J., Olesch, J. and Foken, T.: Documentation of the observation period, 12 May to 8 November 2010, Haean, South Korea, Universität Bayreuth, Abt. Mikrometeorologie, Print, ISSN 1614-8916, Arbeitsergebnisse 45, 2011.

\section{BGD}

9, 2883-2919, 2012

\section{Daytime net ecosystem exchange of carbon dioxide}

P. Zhao and J. Lüers



Printer-friendly Version

Interactive Discussion 


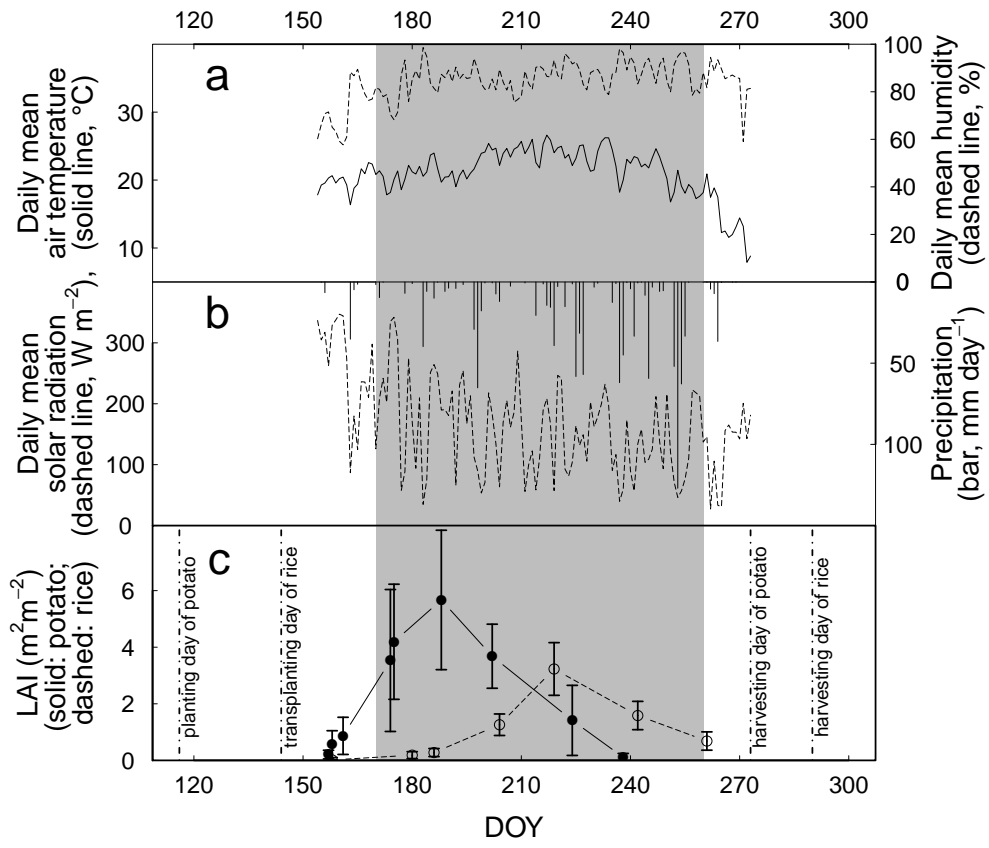

Fig. 1. Meteorological conditions and biomass development at the research sites, including daily mean air temperature (a, solid line), daily mean air relative humidity (a, dashed line), daily sum precipitation (b, bar), daily mean solar radiation (b, dashed line), and leaf area index (LAI, c, solid line representing potato and dashed line representing rice). Error bars are the standard deviations. The vertical dot lines from left to right indicate the planting day of potato, the transplanting day of rice, the harvesting day of potato, and the harvesting day of rice, respectively. The shaded area indicates monsoon and subsequent typhoon season. Dataset from May to October 2010, TERRECO field campaign 2010, Haean Punchbow, Kangwon-do, South Korea.
BGD

9, 2883-2919, 2012

\section{Daytime net ecosystem exchange of carbon dioxide}

P. Zhao and J. Lüers

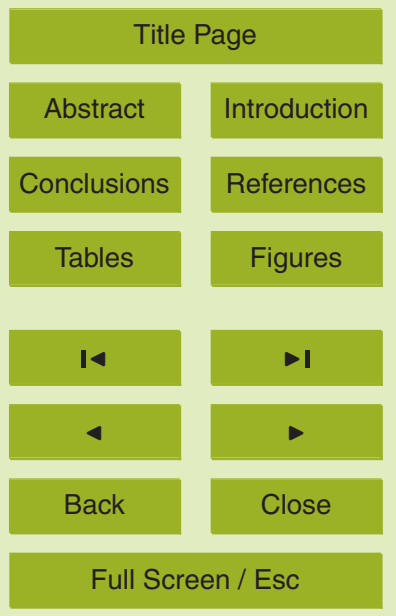

Printer-friendly Version

Interactive Discussion 
BGD

9, 2883-2919, 2012

\section{Daytime net ecosystem exchange of carbon dioxide}
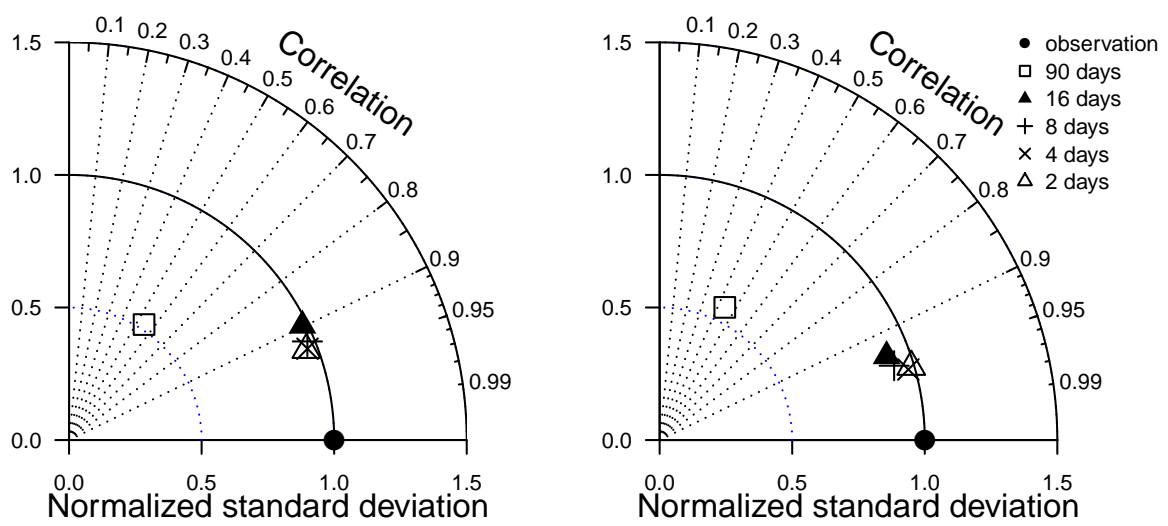

Fig. 2. Taylor diagrams for the performances of simulations applying the time-window scheme at the potato field (a) and the rice field (b). The polar radial distance is the normalized standard deviation (NSD). The polar angle is the correlation coefficient $(R)$. The points denote the mean observation ( $(\bullet)$ and the simulations with time windows of 90 days $(\square), 16$ days $(\mathbf{\Lambda}), 8$ days $(+), 4$ days $(x)$, and 2 days $(\Delta)$. Dataset from May to October 2010, TERRECO field campaign 2010, Haean Punchbow, Kangwon-do, South Korea.
P. Zhao and J. Lüers

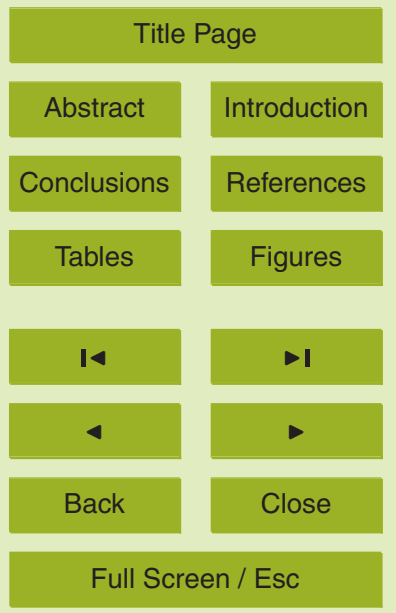

Printer-friendly Version

Interactive Discussion 
BGD

9, 2883-2919, 2012

\section{Daytime net \\ ecosystem exchange of carbon dioxide \\ P. Zhao and J. Lüers}
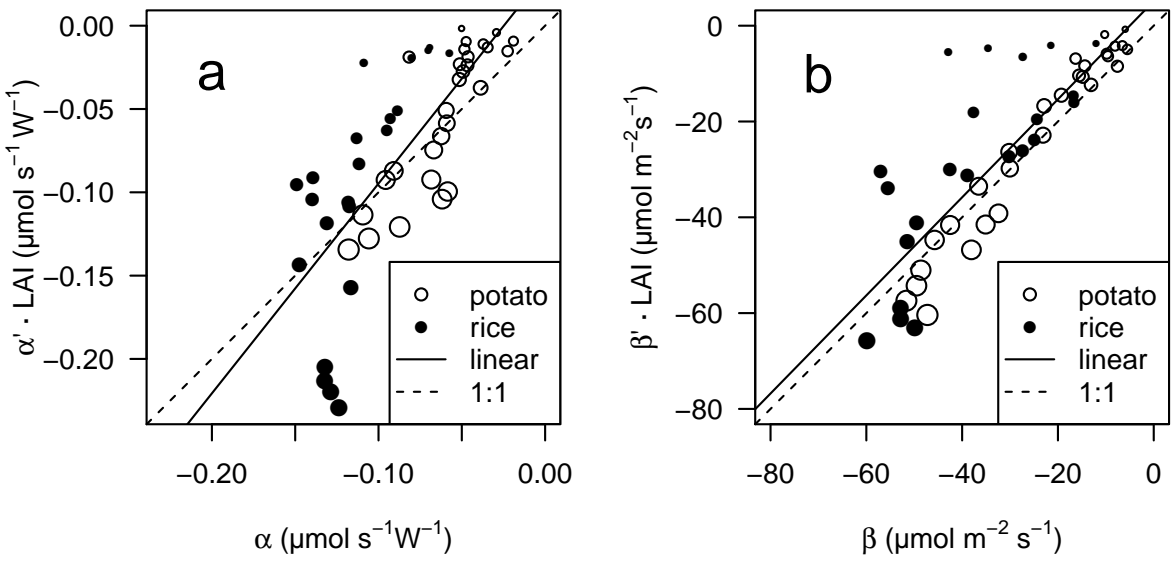

Fig. 3. Comparison between the fitted parameters of the time-window scheme and the leaf area index $(\mathrm{LAl})$ factor scheme at the potato field $(\mathrm{O})$ and the rice field $(\mathbf{0})$. The size of the symbols conceptually denotes the magnitude of LAI (between 0.18 and $5.46 \mathrm{~m}^{2} \mathrm{~m}^{-2}$ ). Dataset from May to October 2010, TERRECO field campaign 2010, Haean Punchbow, Kangwon-do, South Korea.

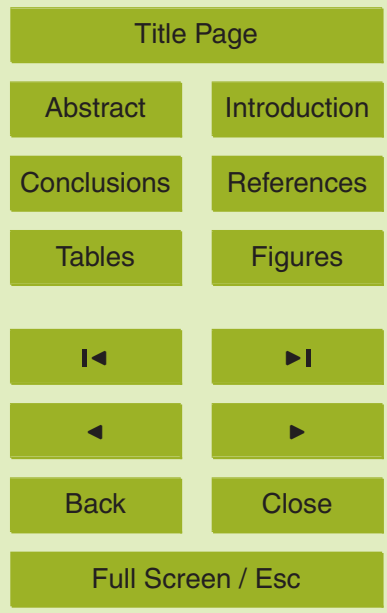

Printer-friendly Version

Interactive Discussion 
BGD

9, 2883-2919, 2012

a

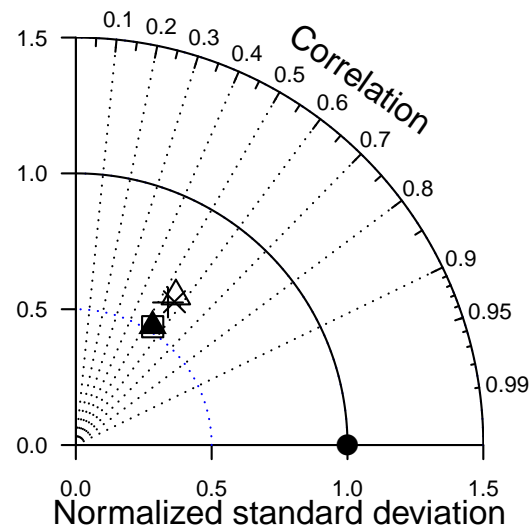

b

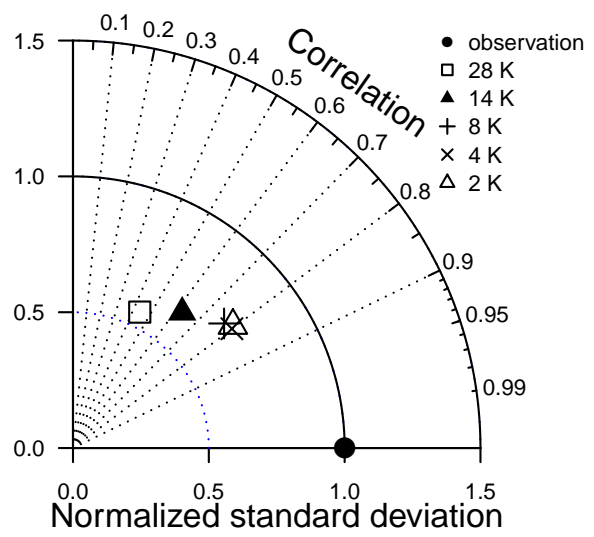

Fig. 4. Taylor diagrams for the performances of simulations applying the temperature binning scheme at the potato field (a) and the rice field (b). The polar radial distance is the normalized standard deviation (NSD). The polar angle is the correlation coefficient $(R)$. The points denote the mean observation $(\bullet)$ and the simulations with temperature classes of $28 \mathrm{~K}(\square), 14 \mathrm{~K}(\boldsymbol{\Delta})$, $8 \mathrm{~K}(+), 4 \mathrm{~K}(\times)$, and $2 \mathrm{~K}(\triangle)$. Dataset from May to October 2010, TERRECO field campaign 2010, Haean Punchbow, Kangwon-do, South Korea.



Printer-friendly Version

Interactive Discussion 


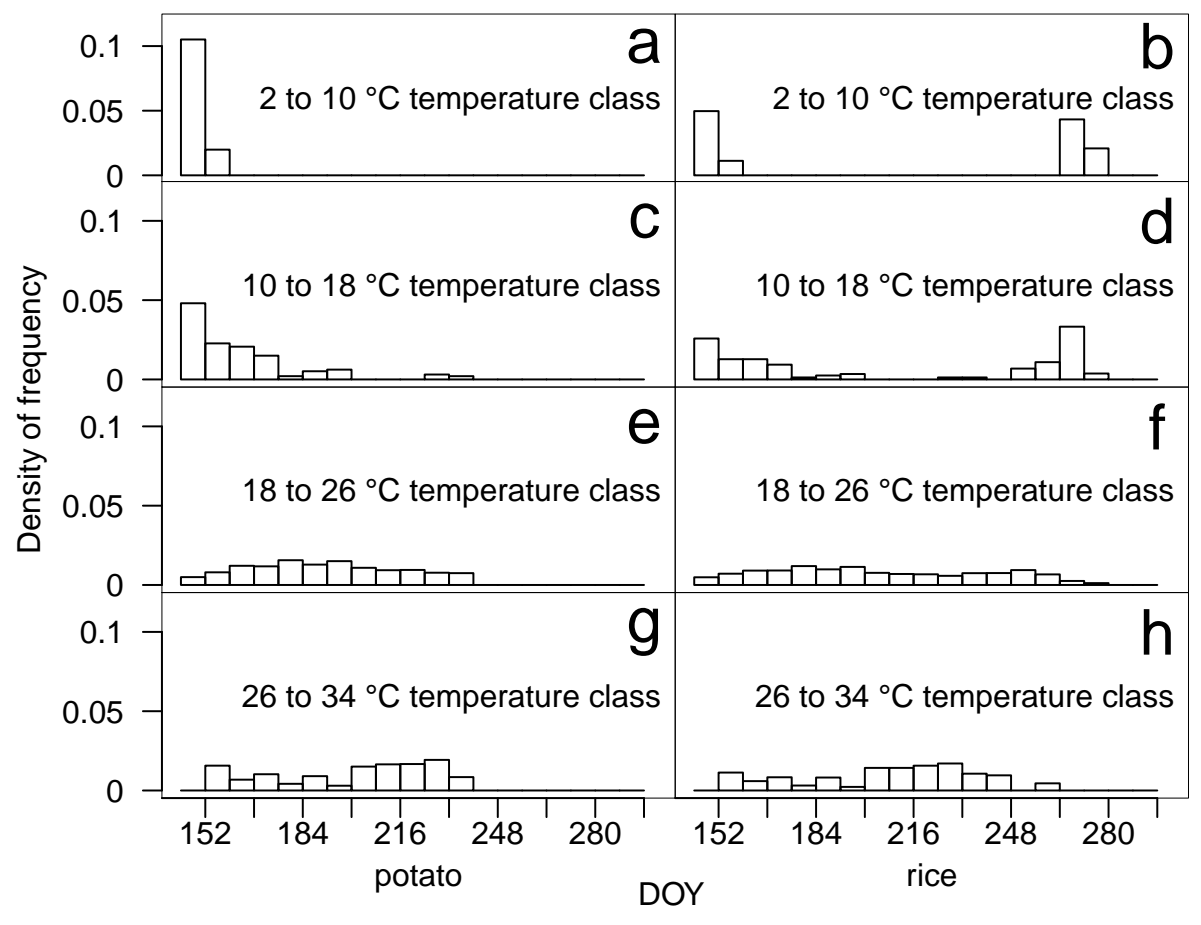

Fig. 5. Temporal distribution of temperature measurements within temperature classes at the potato field (a, c, e, g) and the rice field (b, d, f, h). Dataset from May to October 2010, TERRECO field campaign 2010, Haean Punchbow, Kangwon-do, South Korea.
BGD

9, 2883-2919, 2012

\section{Daytime net ecosystem exchange of carbon dioxide \\ P. Zhao and J. Lüers}

Title Page

Abstract Introduction

Conclusions References

Tables

Figures

14

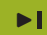

4

Back

Close

\section{Full Screen / Esc}

Printer-friendly Version

Interactive Discussion 
BGD

9, 2883-2919, 2012

\section{Daytime net ecosystem exchange of carbon dioxide}

P. Zhao and J. Lüers

Title Page

Abstract

Introduction

Conclusions

References

Tables

Figures

14

4

Back

Full Screen / Esc

Printer-friendly Version

Interactive Discussion 
BGD

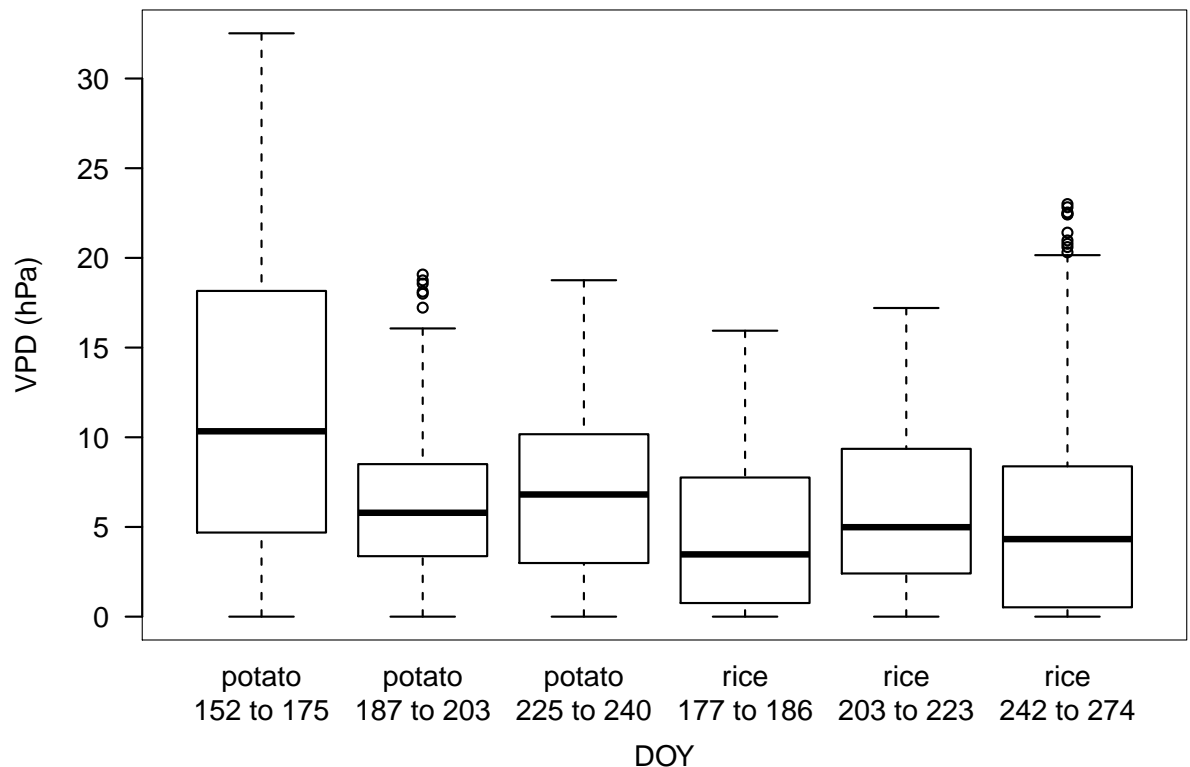

Fig. 7. Boxplot of vapor pressure deficit (VPD) during each measurement period at the potato field and the rice field. The boxplot is composed of the median (solid line), the lower quartile and upper quartile (i.e. the 25th and 75th percentile, box), the lowest datum still within 1.5 times of interquartile range (IQR) of the lower quartile, and the highest datum still within 1.5 IQR of the upper quartile (markers). Dataset from May to October 2010, TERRECO field campaign 2010, Haean Punchbow, Kangwon-do, South Korea.
9, 2883-2919, 2012

\section{Daytime net ecosystem exchange of carbon dioxide}

P. Zhao and J. Lüers

Title Page

Abstract

Introduction

Conclusions

References

Tables

Figures

14

4

Back

Close

\section{Full Screen / Esc}

Printer-friendly Version

Interactive Discussion 

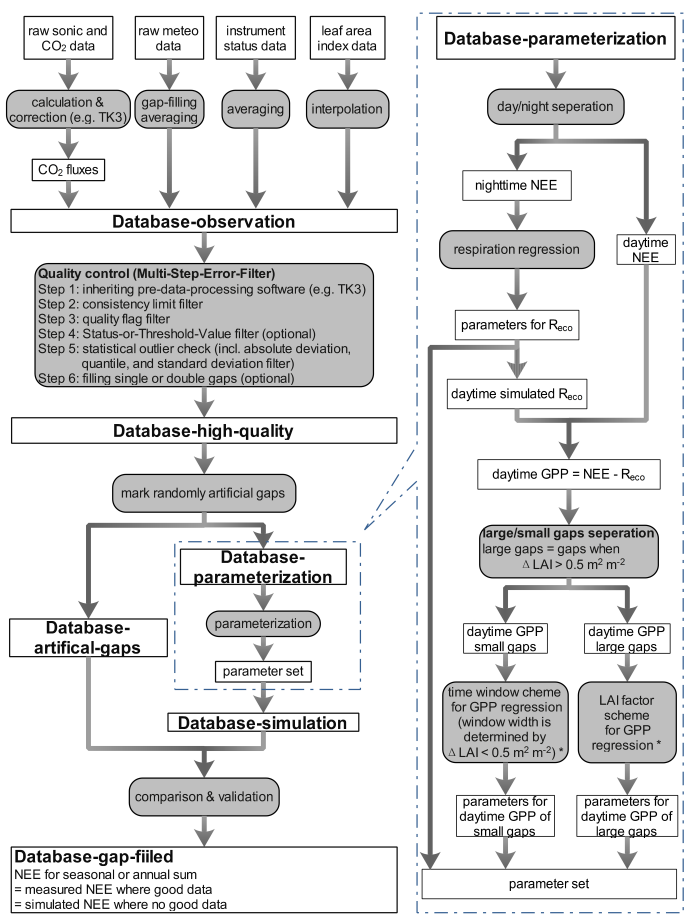

BGD

9, 2883-2919, 2012

\section{Daytime net ecosystem exchange of carbon dioxide}

P. Zhao and J. Lüers

\section{Title Page}

Abstract

Introduction

Conclusions

References

Tables

Figures

14

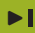

4

Back

Full Screen / Esc

Printer-friendly Version

Interactive Discussion 